\title{
Plant phenological response to microclimatic variations in an alpine zone of Garhwal Himalaya
}

\author{
Rashmi Bijalwan*, M onika Vats and S. P.J oshi
}

Ecology Research Laboratory, Department of Botany, D.A.V. (P.G.) College, Dehra Dun-248001 (Uttarakhand), INDIA *Corresponding author. E-mail: rashmibijalwan@gmail.com

Received: September 12, 2012; Revised received: J anuary 18, 2013; Accepted: February 8, 2013

\begin{abstract}
The impact of microclimatic variations on the developmental stages of common alpine plant species at four primary phenology sites at Dayara meadow of Garhwal Himalayas (Uttarakhand) was studied. The study revealed that the variations in the topographical features and environmental conditions directly influenced the phenology of the alpine plant species. Site I and IV showed great variation in the timing of phenological phases whereas, site III and IV showed approximately similar phenological timings. Anemone obtusiloba and Anaphalis contorta showed early flowering whereas Aconitum heterophyllum, Bupleurum longicaule and Parnassia nubicola flowered in late August and early September. P. nubicola had a shorter flowering period whereas Tanacetum longifolium.and A. nepalensis had the longest flowering period. Taraxacum officinale and Geum elatum flowered twice in the season.
\end{abstract}

Keywords: Alpine, Microclimatic variations, Phenology, Topographical features

\section{INTRODUCTION}

Phenology is the study of the timings of biological phases and the cause of their timings with regard to biotic and abiotic factors. Phenological events are affected by climatic factors like air temperature, soil temperature, precipitation, solar radiation, snow cover, etc and topographical factors like altitude, slope and exposure. High altitude ecosystems are characterized by short growing season and are therefore particularly sensitive to warming trends that affect the length of the growing season. It is believed that the strong correlation between phenology of plants and snowmelt period reflects the short growing season (Walker et al., 1995). In spite of harsh environment, the alpine vegetation is highly variable in species richness. Variation in the topographical features directly influences the microclimatic conditions of the area thereby affecting the growth phases of the plant.

Sundriyal et al. (1987), Ram et al. (1988), Nautiyal et al. (2001) reported phenology of a number of alpine plant species from Garhwal Himalayan region. Other attempts to document the phenology of alpine plants include Bliss (1956), Billings and Mooney (1968), Ram and Arya (1991), Negi et al. (1992) and Kala (1999), Stinson (2004), Hüelber et al. (2006) and, Vashishtha et al. (2009). The objective of the present study was to provide an account of variations in timing of phenology of most common alpine plant species at four different sites varying in topographical features and microclimatic conditions in Dayara, District Uttarkashi of Garhwal Himalaya. ISSN : 0974-9411 (Print), 2231-5209 (Online) All Rights Reserved ๑ Applied and Natural Science Foundation www.ansfoundation.org

\section{MATERIALS AND METHODS}

Study site: Dayara is located in district Uttarkashi of Garhwal Himalaya $\left(30^{\circ} 58^{\prime} 171^{\prime \prime}\right.$ N latitude and $78^{\circ} 33^{\prime} 551^{\prime \prime}$ E longitude) with an elevation ranging between 3308 and $4200 \mathrm{~m}$. Timber line is at $3305 \mathrm{~m}$., above it the vast expanses of flat land show great undulations with frequent hills. The area remains covered with snow from November to April. The snow free period was from May to October ensures vigorous growth of plant species. During the months of primary plant activities, the mean daily maximum temperature ranged between 13.1 and $18.8^{\circ} \mathrm{C}$ and the mean daily minimum temperature between 4.3 and $8.8^{\circ} \mathrm{C}$. The period of clear sky was limited to a few morning hours and was followed by cloud and fog formation. The mean precipitation from May to October is $329.16 \mathrm{~mm}$, was maximum being in the month of July. The high level of atmospheric moisture, precipitation, cloud cover and fog with resultant lower temperatures were the important factors in governing the flowering and fruiting of plants. On the basis of preliminary reconnaissance, four primary phenological sites were established in the study area in 2009. The sites had an extensive population of the ten selected plants for the phenological study. The four sites ranged from $3308 \mathrm{~m}$ to $3600 \mathrm{~m}$ and showed remarkable similarity in the vegetation composition but vary considerably in exposure, slope and depth of surface soil.

The environmental data viz. precipitation, wind velocity, relative humidity, temperature and solar intensity were measured during 2008. Instantaneous and cumulative 
readings were taken at least once a week from early May to October. For precipitation, rain gauge of standard 8" diameter was placed. Instantaneous wind meters and cup anemometer produced data for determination of average wind velocities. Hygrometer, minimum - maximum thermometer, and luxmeter were used to determine relative humidity, mean temperature and solar intensity respectively. Soil temperature at $5 \mathrm{~cm}$ depth was obtained by direct soil thermometer readings.

Phenological changes were observed visually to monitor how plants respond to climate variations. Therefore, detailed phenological records of the ten selected plants were taken from May to October in 2008. The studies were done at weekly interval. The various phenological phases recorded were growth initiation, vegetative phase, flowering, fruiting, seed formation and senescence. The existence of a particular phenophase was considered if $5 \%$ of the individuals showed that phenophase. The plants were categorized on the basis of growth initiation time as early (up to 2nd week of May) and late (May end to June). They were also categorized on the basis of flowering time as early (June), intermediate (July) and late (August). A brief description of the plants is given in Table 1.

\section{RESULTS AND DISCUSSION}

The topographical and environmental characteristics of the sites are presented in Table 2. The soil temperature at $5 \mathrm{~cm}$ depth at which many species showed most abundant root growth averaged between $7.2^{\circ} \mathrm{C}$ to $12.5^{\circ} \mathrm{C}$. Site I and site III were moist while site II and IV were dry sites on the basis of soil moisture estimates. The analysis of soil samples revealed the clayey-loam texture, acidic nature (pH 4.8 - 5.8), rich organic matter (16-27\%), and is low in soluble salts (conductivity $0.1 \mathrm{mmhos}$ ).

During May-October, the study area received $1975 \mathrm{~mm}$ rainfall, maximum being in the month of July $(751 \mathrm{~mm})$. During this period the mean daily maximum air temperature ranged between $13.1-18.8^{\circ} \mathrm{C}$ and the mean daily minimum between 4.3 and $8.8^{\circ} \mathrm{C}$ (Table 1). The period of rainfall was during mid June to mid September and there was marked absence of typical summer with clear sky. It distinguishes the alpine climate of Garhwal Himalaya from that of lower Himalayan ranges.

The ten plants selected were all perennials. Out of these, two plants fall under dwarf erect forbs, five under dwarf spreading forbs, two under tall spreading forbs and only one under tall erect forbs. The perenating organs of these plants initiated to grow as soon as the snow melted. Out of the ten plants seven plants initiated their growth in the first week of May whereas Aconitum heter ophyllum and Parnassia nubicola started it in the third week of May. Bupleurum longicaule was noticed as very late germinating forb among all. It initiated its growth late in
June. The month of May and June observed vigorous vegetative growth as the temperature increased. Anemone obtusiloba had the shortest vegetative phase while Taraxacum officinale took maximum time for vegetative growth followed by Potentilla atrosanguinea, Geranium wallichianum and P. nubicola. The plants showed much variation in the budding period. Geum elatum and $A$. obtusiloba took minimum time of only two weeks to open into flowers whereas $A$. heterophyllum had the longest bud phase of about six week. The flowering period of the ten forbs varied from mid June to early September. Anemone obtusiloba being an early flowering plant species bloomed in a short duration after bud enlargement whereas A. heterophyllum, P. nubicola and B. Iongicaule flowered in late August and early September. The flowering period varied for different plant species. P. nubicola was observed with minimum duration of flowering of only two weeks. On the other hand Anaphalis contorta and Tanacetum Iongifolium had the maximum duration of flowering. Fruiting began as early as July and peaked during late August. Gradual senescence started from August and was accelerated by the onset of severe climatic conditions by the end of September. G. elatum and T. officinale flowered twice showing deviation from the normal phenological pattern. The greatest variation in the timing of phenological phases for the species was recorded at site I and IV where as site III and IV present on totally opposite exposure have shown similar phenological timings (Fig. 1).

Timing of snow release strongly affects initiation of growth and flowering of most alpine species (Billings and Bliss, 1959, Holway and Ward, 1963, Holway and Ward, 1965, Spomer and Salisbury, 1968, Fareed and Caldwell, 1975, Bock, 1976 and Owen, 1976) so as the melting snow exposes the land, the early growing species initiate their development. Since the plant species under study were perennial, so most of them showed growth initiation in the month of May with the snow melt. Ambient temperature is suitable for the plant growth at the time of snowmelt and thus strongly favors the initiation of growth of plant species (Holway and Ward, 1965, Kudo, 1991, Kudo and Suzuki, 1999, Kudo and Hirao, 2006). Oberbauer and Billings (1981) have reported that the shallow root system of some alpine species favors early growth. Alpine ecosystems have limited resources available for plant growth and these resources are present for only a limited time, the phenology of growth and reproduction is thus of special interest in these systems (Sorenson, 1941, Billings and Bliss, 1959, Holway and Ward, 1965, Wielgolaski, 1975, Jackson and Bliss, 1984, Shaver et al., 1986). Kudo and Hirao (2006), Ram et al. (1988), May and Weber (1982) and Holway and Ward (1965) reported that plant growth in alpine and tundra is controlled by the disappearance of snow cover. 

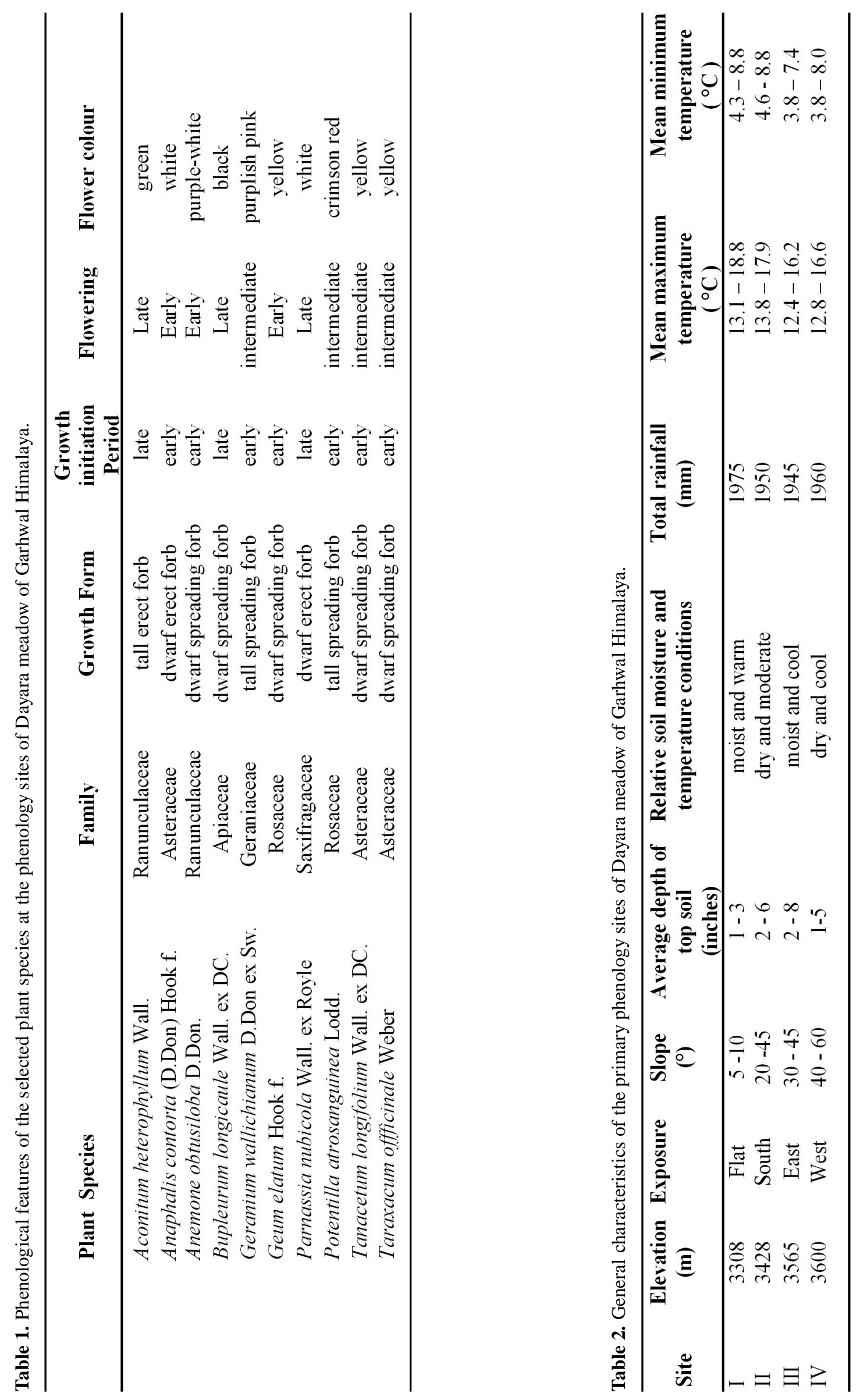
Aconitum heterophyllum

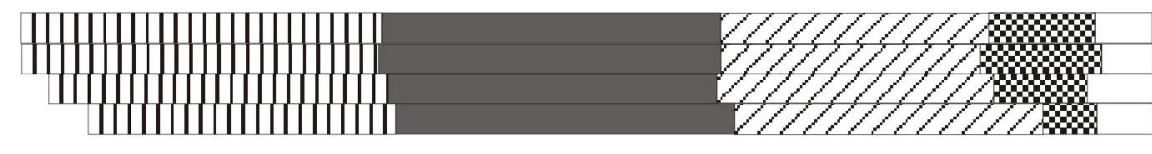

Anaphalis contorta

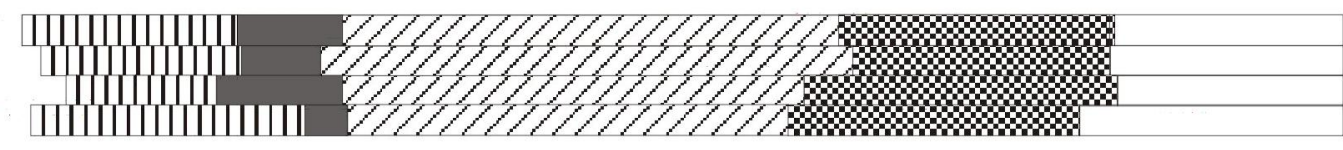

Anemone obtusiloba

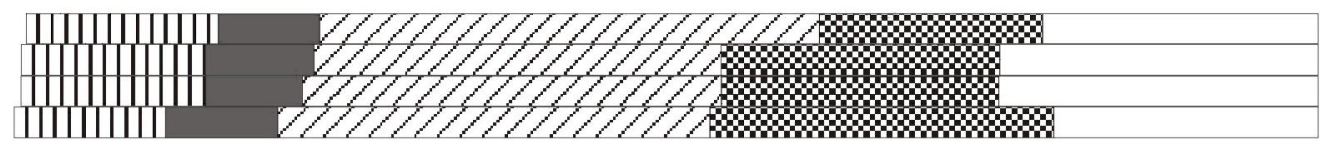

Bupleurum longicaule

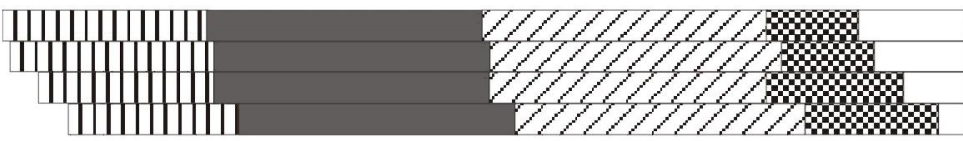

Geranium wallichianum

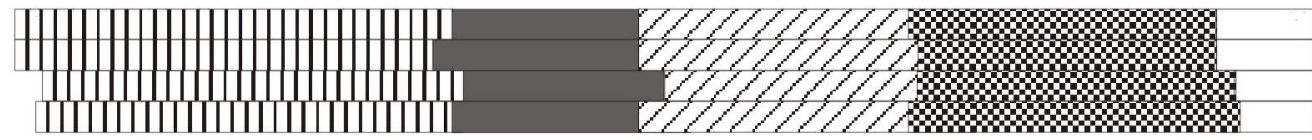

Geum elatum

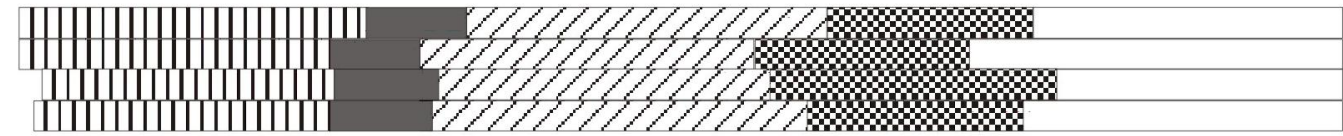

Parnassia nubicola

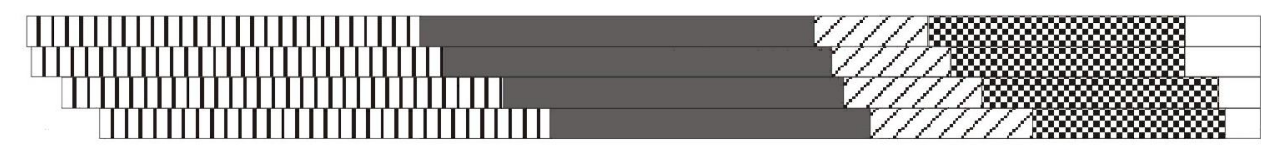

Potentilla atrosanguinea
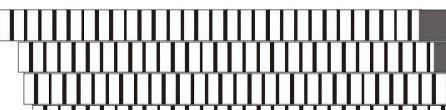

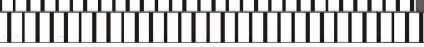
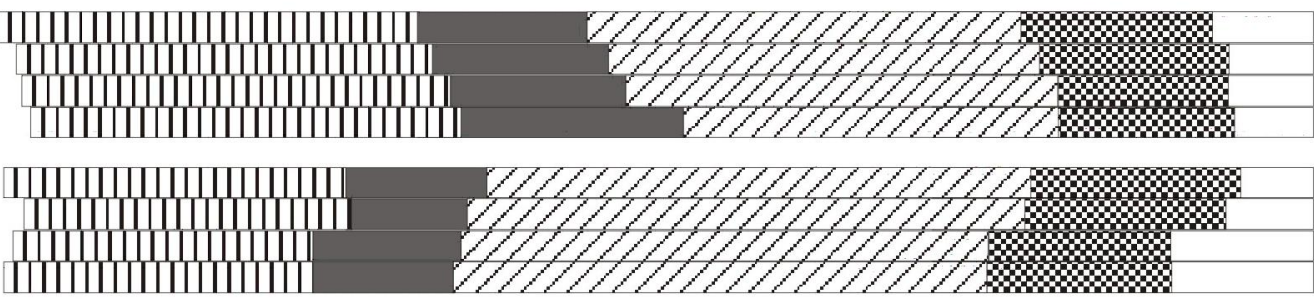

Tanacetum longifolium

Taraxacum offficinale

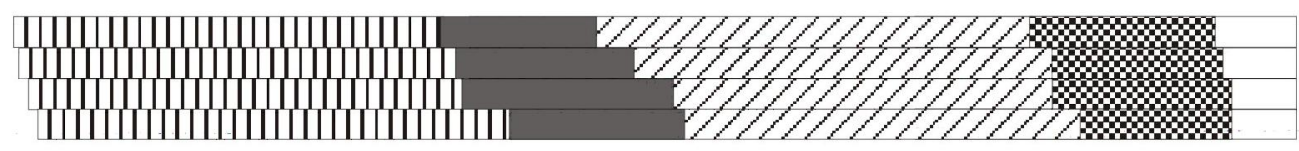

III Vegetative phase
Budding phase
Flowering phase
Fruiting phase

Senesence phase

Fig. 1. Phenological records of the selected ten plant species at the four phenological sites of Dayara meadow of Garhwal Himalaya.

Snow cover has a controlled effect on the flowering period of the plant species (Kudo, 1991, 1992) and the timing of flowering period determines the reproductive success of the plant species (Thórhallsdóttir, 1998 and Hülber et al., 2010). The abundant water supply and gradual increase in the soil temperature plays an important role in the early development of these species. The ability of these species to absorb water at low soil temperature helps them to initiate their growth soon after snow melt in late April and early May However the growth ignition peaked in early June, 30-40 days after the completion of snowmelt when the day temperature in the open averaged $16^{\circ} \mathrm{C}$ (Ram et al., 1988). Further with the increase in soil and air temperature these species show vigorous growth 
resulting in early bud formation and early flowering as in case of Anemone obtusiloba and G. elatum. The early flowering in these species is also associated with short period of vegetative growth with low temperature threshold while the long periods of vegetative growth with high temperature thresholds were associated with late flowering as in case of A. heterophyllum, P. nubicola and B.longicaule. These results find support of the conclusion by Lindsey and Newman (1956). The blomming phase in many late flowering alpine plants is not controlled by snow or soil conditions but by the photoperiodic triggers (Kçrner 1999, Keller and Kçrner 2003, Giménez et al., 2007).

The marked differences in the phenological timings at the four sites were observed due to the adaptations of the plants to their microclimatic variations. The difference in the growth initiation period of plants at site I and IV were probably due to the great variation in the topography and relative soil moisture and temperature condition. There was a delay in the phenological timings at site IV. This delay may be attributed to heavy snow accumulation and slow melting at the site due to more altitude (Sorenson, 1941). On the other hand site III and IV present on totally opposite exposure have shown approximately similar phenological timings. This may be due to approximately similar slope angle and air and soil temperature. It appears that in these altitudes aspect has little effect on flowering. Holway and Ward (1965) have attributed this similarity due to the snow free environment at the same time. Similarly, timing of flowering of a common species occurring at different sites also varied due to photoperiodic responses (Daubenmire, 1959) and variability in environmental conditions.

Plants like T. officinale and G. elatum flowered twice in the season. This may be attributed to higher production of carbohydrates (Holway and Ward, 1965). Also these two along with Anemone obtusiloba showed re-initiation of vegetative growth especially at site I. This may be probably due to ample water supply in the later period also, as the site receives water from the higher slopes and has comparatively higher temperature, which is most critical for plant activity at high mountain elevations (Daubenmire, 1954). Thus from the study it is clear that the continuous change in environment creates fluctuation in phenology of plants. These fluctuations are due to the response of the plants to their respective microclimatic changes at different altitudes, slope and exposure.

\section{REFERENCES}

Billings, W.D. and Bliss, L.C. (1959). An alpine snowbank environment and its effects on vegetation, plant development and productivity. Ecology, 40: 389-397.

Billings, W.D. and Mooney, H.A. (1968). The ecology of arctic and alpine plants. Biological Reviews, 43: 481-529.

Bliss, L.C. (1956). A comparision of plant development in microenvironments of arctic and alpine tundras. E cological Monograph, 26: 303-307.

Bock, J.H. (1976). The effects of increased snowpack on the phenology and seed germinability of selected alpine species. In Ecological Impacts of Snowpack Augmentation in the San Juan Mountains of Colorado. Steinhoff, H.W. and Ives, J.D. (eds). Final report to the Division of Atmospheric Water Resources Management, Bureau of Reclamation, Denver, Colorado, USA.

Daubenmire, R.F. (1954). Alpine timberlines in the Americas and their interpretation. Butler University Botanical Studies, 11: 119-136.

Daubenmire, R.F. (1959). A canopy cover method of vegetational analysis. Nor thwest Science, 33: 43-66.

Fareed, M. and Caldwell, M.M. (1975). Phenological patterns of two alpine tundra plant populations on Niwot Ridge, Colorado. Northwest Science, 49: 17-23.

Giménez-Benavides, L., Escudero, A. and Iriondo J.M. (2007). Reproductive limits of a late-flowering high-mountain Mediterranean plant along an elevational climate gradient. New Phytologist, 173: 367-382.

Holway, J.G. and Ward R.T. (1963) Snow and melt water effects in an area of Colorado alpine. Am. Midland Naturalist, 69: 189-197.

Holway, J.G. and Ward R.T. (1965). Phenology of alpine plants in Northern Colorado. E cology, 46: 73-83.

Huelber, K., Gottfried, M., Pauli, H., Reiter, K., Winkler, M., and Grabherr, G. (2006). Phenological responses of snowbed species to snow removal dates in the Central Alps: implications for climate warming. Arctic, Antarctic and Alpine Research, 38: 99-103.

Hülber, K., Winkler, M. and Grabherr, G. (2010). Intraseasonal climate and habitat-specific variability controls the flowering phenology of high alpine plant species. Functional E cology, 24: 245-252.

Jackson, L.E. and Bliss, L.C. (1984). Phenology and water relations of three plant life forms in a dry tree-line meadow. Ecology, 65: 1302-1314.

Kala, C.P. (1999). Phenology of alpine plants in the Valley of Flowers, National Park and Hemkund, Western Himalaya. Indian Forester, 125: 581-590.

Keller, F. and Kçrner, C. (2003). The role of photoperiodism in alpine plant development. Arctic, Antarctic, and Alpine Research, 35:361-368.

Kudo, G. (1991). Effects of snow-free period on the phenology of alpine plants inhabiting snow patches. Arctic, Antarctic and Alpine Resear ch, 23: 436-443.

Kudo, G. (1992). Pre-flowering and fruiting periods of alpine plants inhabiting a snow-bed. J. Phytogeogr. Taxon., 40: 99106.

Kudo, G. and Hirao, A.S. (2006). Habitat-specific responses in the flowering phenology and seed set of alpine plants to climate variation: implications for global-change impacts. Population Ecology, 48: 49-58.

Kudo, G. and Suzuki, S. (1999). Flowering phenology of alpine plant communities along a gradient of snowmelt timing. Polar Bioscience, 12: 100-113.

Kçrner, C. (1999). Alpine plant life: functional plant ecology of high mountain ecosystems (338 pp). Springer, Berlin.

Lindsey, A. and Newman, J. (1956). Use of official weather 
data in spring time-Temperature analysis of an Indiana phenological record. Ecology, 37: 812-823.

May, D.E. and Webber, P.J. (1982). Spatial and temporal variation of the vegetation and its productivity, Niwot Ridge Colorado. In Ecological Studies in the Colorado Alpine. (Ed. by J.C. Holfpenny). University of Colorado, Institute of Arctic and Alpine Research, 37: 35-62.

Nautiyal, M.C., Nautiyal, B.P. and Prakash, V. (2001). Phenology and growth form distribution in an alpine pasture at Tungnath, Garhwal Himalaya. M ountain Research and D evelopment, 21(2): 177-183.

Negi, G.C.S., H.C. Rikhari and S.P. Singh. (1992). Phenological features in relation to growth forms and biomass accumulation in an alpine meadow of the Central Himalaya. Vegetatio, 101: 161-170.

Oberbauer, S.F. and Billings W.D. (1981). Drought tolerance and water use by plants along an alpine topographic gradient. O ecologia, 50: 325-331.

Owen, H.E. (1976). Phenological development of herbaceous plants in relation to snowmelt date. In Ecological impacts of snowpack augmentation in the San Juan Mountains of Colorado. H.W. Steonhoff and J.D. Ives (eds). U.S Department of Interior, Division of Atmospheric Water Resources Management, Bureau of Reclamation, Denver, Colorado, U.S.A., pp. 323-341.

Ram, J. and Arya, P. (1991). Plant forms and vegetation analysis of an alpine meadow of Central Himalaya, India. Proceedings of the National Science Academy, 57: 311-318.

Ram, J., Singh, S.P. and Singh, J.S. (1988). Community level phenology of grassland above treeline in Central Himalaya. Arctic and Alpine Research, 20: 325-332.
Shaver, G.R., Fetcher, N. and Chapin, F.S. III. (1986). Growth and flowering in Eriphorum vaginatum: annual and latitudinal variation. E cology, 67: 1524-1535.

Sorenson, T. (1941). Temperature relations and phenology of the Northeast Greenland flowering plants. M eddelelser om Grønland, 125: 1- 305.

Spomer, G.G. and Salisbury, F.B. (1968). Eco-physiology of Geum turbinatum and implications concerning alpine environments. B otanical Gazette, 129: 33-49.

Stinson., K.A. (2004). Effects of snowmelt timing and neighbor density on the distribution of the high altitude plant Potentilla diversifolia. Arctic, Antarctic and Alpine Research, 37(3): 379-386.

Sundriyal, R.C., Joshi, A P. and Dhasmana, R. (1987). Phenology of high altitude plants at Tungnath in the Garhwal Himalaya. Tropical Ecology, 28: 289-299.

Thórhallsdóttir, T.E. (1998). Flowering phenology in the central highland of Iceland and implications for climatic warming in the Arctic. O ecologia, 114: 43-49.

Vashistha, R.K., Rawat, N., Chaturvedi, A.K., Nautiyal, B.P., Prasad, P. and Nautiyal, M.C. (2009). An exploration on the phenology of different growth forms of an alpine expanse of North- West Himalaya, India. New York J ournal, 2(6): 1554-0200.

Walker, M.D., Ingersoll, R.C. and Webber, P.J. (1995). Effects of Interannual climate variation on phenology and growth of two alpine forbs. Ecology, 76(4): 1067-1083.

Wielgolaski, F.E. (1975). Primary Productivity of alpine meadow communities. Fennoscandian Tundra Ecosystems. Part I: Plants and Microorganisms, edited by F. E. Wielgolaski (pp121-128), Springer-Verlag, New York. 